Images in Clinical Neurology / Klinik Görünüm

DOI:10.4274/tnd.2022.73483

\title{
LATE ONSET EPILEPSY WITH HYPONATREMIA
}

\section{HIPONATREMI İLE GIDEN GEÇ BAŞLANGIÇLI EPILEPSI OLGUSU}

İngilizce Kısa Başlık: Late onset epilepsy with hyponatremia

Türkçe Kısa Başılı: Hiponatremi ile giden epilepsi olgusu

Mahmut Bilal Çaman ${ }^{1}$, Fatma Küçük ${ }^{2}$, Semai Bek ${ }^{1}$, Gülnihal Kutlu ${ }^{1}$

${ }^{1}$ Mugla Sitkı Koçman University, Faculty Of Medicine, Department Of Neurology, Mugla, Turkey

${ }^{2}$ Mugla Training And Research Hospital, Mugla, Turkey

\section{Corresponding Author Information}

Asistan Mahmut Bilal Çaman

mbilalcaman@gmail.com

05393078797

https://orcid.org/0000-0001-7956-5677

20.08.2021

17.01.2022

Keywords: Encephalitis, LGI1, seizure, immunotherapy, epilepsy

Anahtar Kelimeler: Ensefalit, LGI1, nöbet, immünoterapi, epilepsi

\section{Dear editor;}

Autoimmune encephalitis refers to a group of subacute-onset diseases that may progress with memory impairment, changes in state of consciousness, movement disorders, psychosis, autonomic disorders and epileptic seizures. Paraneoplastic and immunological causes have been accused in etiology. (1) A rare type of autoimmune encephalitis is Anti leucine-rich glioma inactivated 1 (LGI1) associated autoimmune limbic encephalitis (ALLE) with temporal lobe seizures and hyponatremia.(2) ALLE is more common in men and the age of onset is most often between the ages of 61 and 64. (3)

A seventy-four-year-old female patient was brought to the emergency room due to an epileptic seizure at home. From the history of her family; it was clear that she had behavioral arrest, perseveration and clonic seizures in the right hand. Blood tests showed a sodium value of 104 $\mathrm{mmol} / \mathrm{l}$ (normal value: 136-145 mmol/l). $3000 \mathrm{mg}$ Levetiracetam (LEV) was given intravenously (iv) as loading therapy and for supplemental treatment LEV $1000 \mathrm{mg}$ iv was given daily. The patient was treated with intravenous hypertonic saline for hyponatremia.

The patient's cranial Magnetic Resonance Imaging (MRI) showed an increase in the T2A signal along with an increase in volume at the left hippocampus and temporal lobe (Figure 1,2). When the MRI of the patients with ALLE are examined; a hyperintense appearance, often bilateral, in T2A and flair sequences in the mesial temporal lobe or hippocampus, extending to the amygdala, striatum, and insula, can be observed. (3)

In our patient's Electroencephalography (EEG) record sparse left temporal theta paroxysms were observed (Figure 3,4). Although there is no specific EEG finding in the ALLE patients', interictal epileptiform discharges can be observed. In addition, the continuous slow activity observed during 
the EEG recording or Frontal Intermittant Rhythmic Delta Activity (FIRDA) suggest there may be an immunological cause in patients. $(1,3)$

No significant finding was observed in the patient's Cerebrospinal Fluid (CSF) examination. After the exclusion of infectious etiology, paraneoplastic autoantibody panel (which includes antibodies for Amphiphysin, CV2, PNMA2 (Ma2/Ta), Ri, Yo, Hu, Recoverin, SOX1, Titin, Zic4, GAD65, $\operatorname{Tr}(\mathrm{DNER}))$ was studied and the result was negative. In the autoimmune encephalitis panel, Anti-LGI1 was positive. Cancer screening tests were negative. It is known that only $11 \%$ of the patients can have a primary malignancy. (4)

The occurrence of seizures with hyponatremia creates the misconception that these seizures develop symptomatically secondary to hyponatremia. For this reason, many patients with ALLE can be misdiagnosed and many of these patients only receive symptomatic seizure treatment and treatment for hyponatremia. Without treatment for autoimmune disease, and objective improvement cannot be observed in these people.

Immunosuppressive and immunomodulatory agents and methods are used in the treatment. Intravenous immunoglobulin ((IVIg), plasmapheresis or intravenous pulse steroid therapy are used as the first choice. (3) The patient was given IVIg therapy for five days, with the dose of 0.4 $\mathrm{g} / \mathrm{kg} /$ day as an immune regulatory therapy for her diagnosis. With improved consciousness and no observed seizures the patient was discharged with oral steroid and supplemental LEV $1000 \mathrm{mg} / \mathrm{day}$ therapy. No epileptic seizures were observed in the follow-up of the patient.

\section{References:}

1- Leyla BK, Ebru A, Otoimmün ensefalit ve paraneoplastik nörolojik sendromlarda s1k karşılaşılan EEG özellikleri, Epilepsi 2016;22(Suppl. 1):30-36.

2- $\quad$ Lai M, Huijbers MG, Lancaster E et al. Investigation of LGI1 as the antigen in limbic encephalitis previously attributed to potassium channels: a case series. Lancet Neurol 2010;9(8):776-85.

3- Mohan K, Jose AC, Tulsi S, Rajesh G. Rare case of Anti-LGI1 limbic encephalitis with new onset epilepsy: a case report. Cureus 2019;11(5):e4608.

4- $\quad$ Neşe D, Sik ve dirençli nöbetlerle izlenen Anti-LGI1 ilişkili otoimmün limbik ensefalit hastas1. Epilepsi 2016;22(Suppl. 1):67-71.

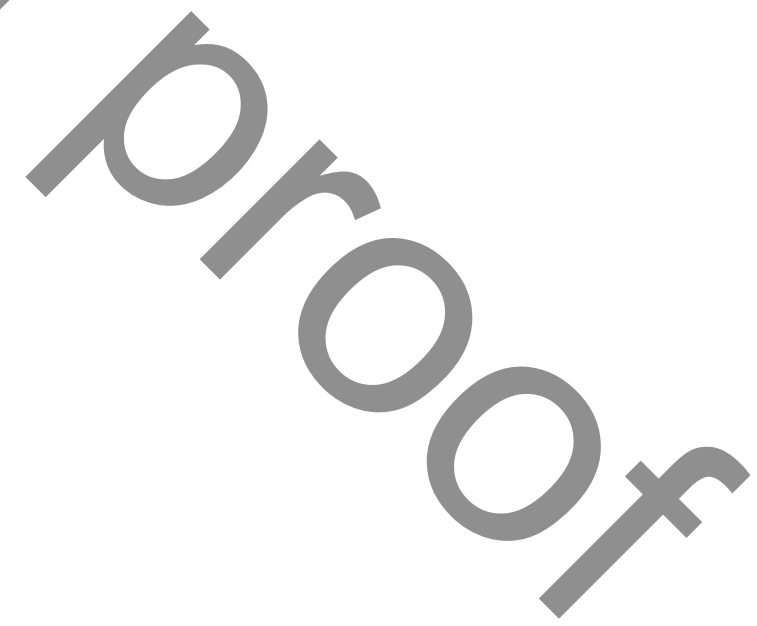




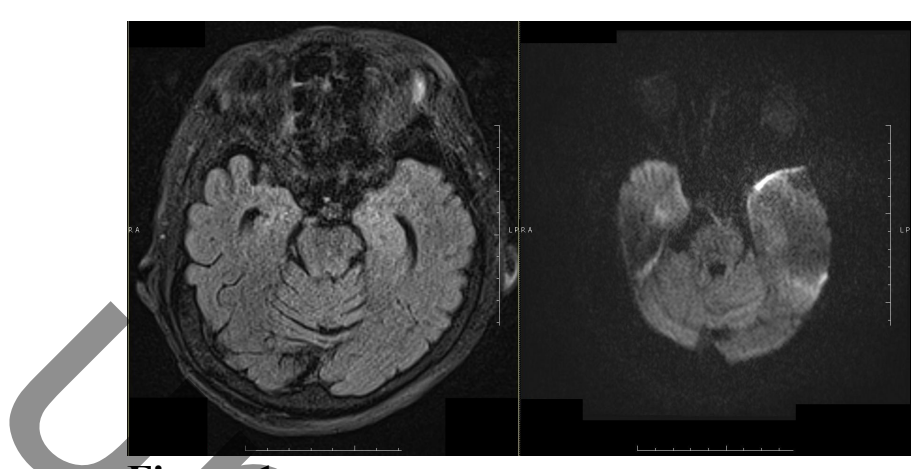

\section{Figure 1}

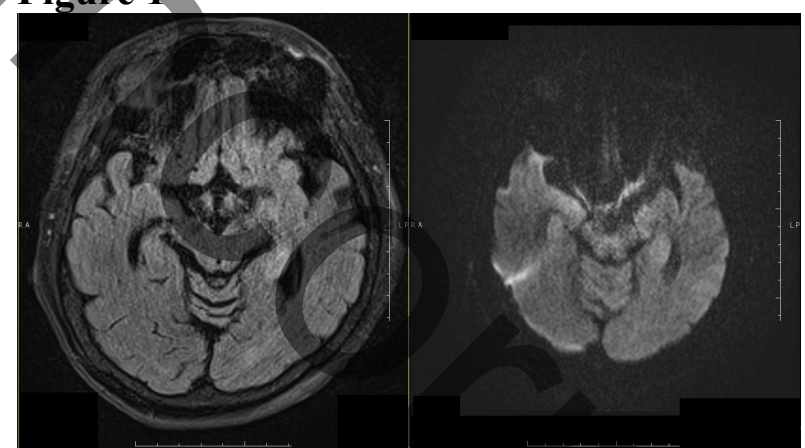

Figure 2

Figure 1, 2: Cranial Magnetic Resonance Imaging (MRI); increase in the T2A signal along with an increase in volume at the left hippocampus and temporal lobe.

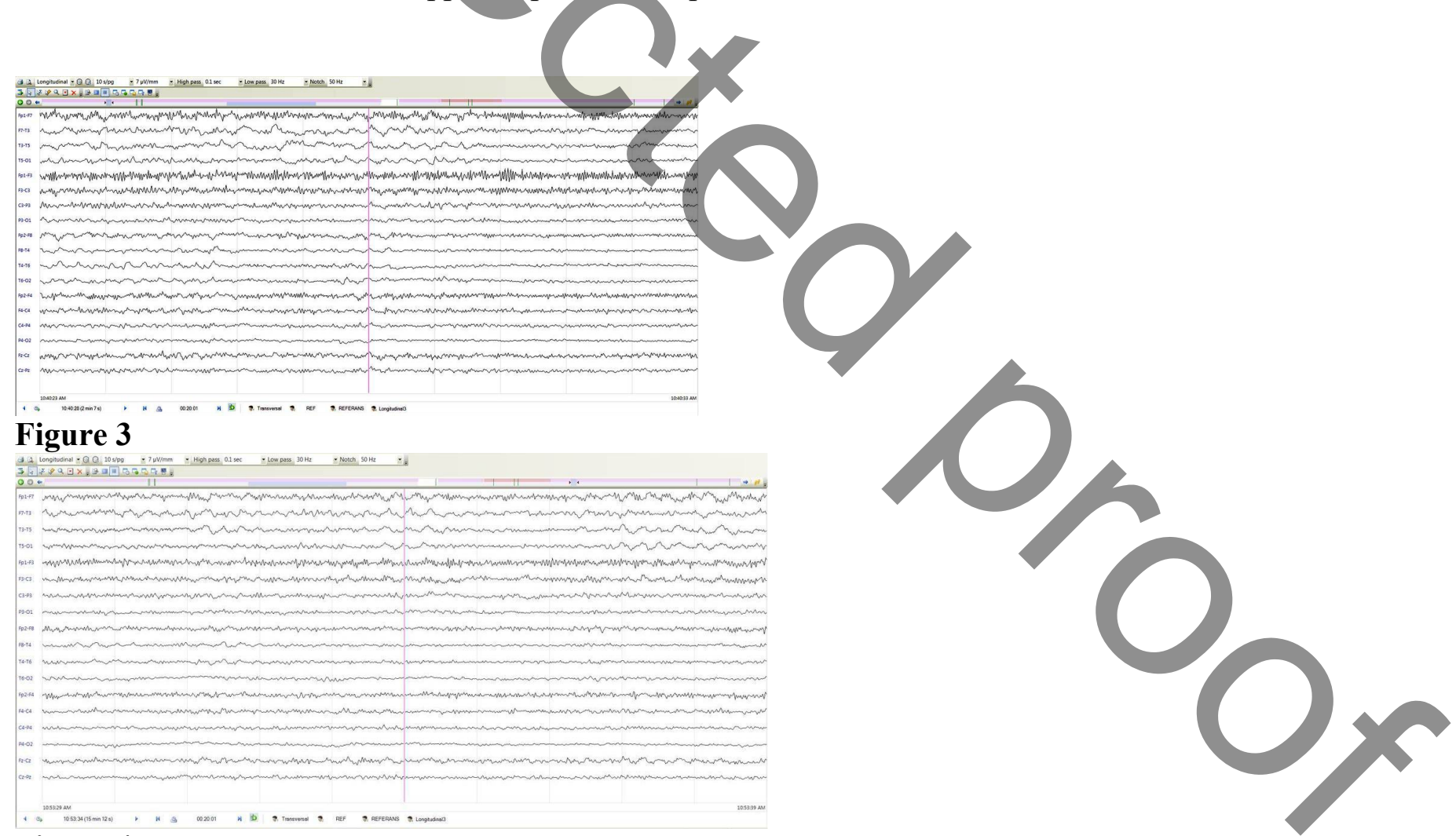

\section{Figure 4}

Figure 3, 4: Sparse left temporal theta paroxysms in the Electroencephalography (EEG) record. 